\title{
Authentic leadership, followership, and psychological capital as antecedents of work engagement
}

\section{Marieta du Plessis \& Adré B. Boshoff}

To cite this article: Marieta du Plessis \& Adré B. Boshoff (2018) Authentic leadership, followership, and psychological capital as antecedents of work engagement, Journal of Psychology in Africa, 28:1, 26-32, DOI: 10.1080/14330237.2018.1438832

To link to this article: https://doi.org/10.1080/14330237.2018.1438832

曲 Published online: 12 Mar 2018.

Submit your article to this journal $\widetilde{ }$

III Article views: 1138

Q View related articles

View Crossmark data \lceil

Citing articles: 1 View citing articles 지 


\title{
Authentic leadership, followership, and psychological capital as antecedents of work engagement
}

\author{
Marieta du Plessis* (iD) and Adré B. Boshoff \\ Department of Industrial Psychology, University of the Western Cape, Bellville, South Africa \\ *Corresponding author email: mduplessis@uwc.ac.za
}

\begin{abstract}
The present study investigated authentic leadership, psychological capital, and followership behaviour influences on work engagement of employees. Respondents were 901 South African employees within the healthcare industry organisation $(n=647)$ and mining industry $(n=254)$. The employees completed questionnaires on authentic leadership, psychological capital, and followership behaviour, and work engagement. Results following structural equation modelling and mediation analysis suggest work engagement to be explained by the psychological capital of the employee rather than by authentic leadership qualities. Improving employee psychological capital has the potential to enhance the levels of work engagement of employees.
\end{abstract}

Keywords: authentic leadership, followership, healthcare industry, mining industry, positive organisational behaviour, psychological capital, structural equations modelling, work engagement

\section{Introduction}

Work engaged employees are up to two times more productive than those who are less engaged (Harter, Schmidt \& Keyes, 2002): they work with passion, and drive innovation that thrusts the organisation forward (Attridge, 2009). For this reason, human resource managers aim at improving the work engagement of employees to boost organisational productivity and success (Harter, Schmidt \& Keyes, 2002), and increase retention, decrease absenteeism, improve productivity, and enhance personal well-being (Robertson \& Cooper, 2009). However, increasing work engagement sustainably requires an understanding of related influences from the employee's perspective (Truss, Delbridge, Alfes, Shantz, \& Soane, 2014). In this study, we sought to examine employee oriented antecedents of work engagement that is important to organisation productivity.

\section{Employee work engagement: Nature and antecedents}

Work engagement refers to an individual's relationship with his or her job, rather than his or her relationship with the organisation (Schaufeli, 2014). It is defined by three components: vigour, absorption, and dedication (Schaufeli \& Bakker, 2003). Vigour is characterised by high energy levels and mental resilience while working, whereas absorption signifies being fully focused and embedded in ones' work. Work dedication encompasses being involved in one's work and experiencing significance, enthusiasm, inspiration, pride, and challenge from it (Bakker \& Demerouti, 2008; Schaufeli, Bakker, \& Salanova, 2006).

Work engaged employees have high levels of organisational citizenship behaviour (Rich, LePine, \& Crawford, 2010), enhanced overall performance (Bakker \& Demerouti, 2008; Cameron \& Spreitzer, 2012; Schaufeli \& Salanova, 2007), high levels of job satisfaction, and reduced levels of turnover intention (Bakker \& Demerouti, 2008). By contrast, work disengaged individuals show characteristics of withdrawal and defensiveness, resulting in behaviours that deplete time, effort, earnings, and morale (Dawsey \& Taylor, 2011).

The person and organisational context factors of psychological capital (PsyCap), followership, and leadership are important in fostering work engagement within employees. For instance, the individual's PsyCap of self-efficacy, hope, optimism, resilience, and followership is associated with being work energised and productive as well as with job satisfaction (Luthans, Avolio, Avey, \& Norman, 2007). Followers in the workplace have an active role to play in organisational success and therefore success is not solely dependent on dynamic leaders (Baker, 2007). Kelley (1992) expressed the view that authentic workplace leaders contribute a maximum of $20 \%$ to organisational success, whilst followers contribute an estimated $80 \%$ to organisational success. Authentic leaders embody four behavioural tendencies; namely self-awareness, relational transparency, balanced processing, and internalised moral perspective (Luthans \& Avolio, 2003). They support and build follower trust (Wang \& Hsieh, 2013) through cultivating supportive co-worker relationships for work organisational success (Barrick, Thurgood, Smith, \& Courtright, 2015; May, Gilson, \& Harter, 2004). Authentic leaders utilise people development techniques, creating a context where employees feel supported, empowered, recognised, and work engaged (Luthans \& YoussefMorgan, 2017).

\section{Work engagement in South Africa}

According to a global Gallup poll, 46\% of South African workers had described themselves as "not engaged" in their work, while $45 \%$ had described themselves as "actively disengaged" (Gallup, 2013). The effects of a disengaged workforce include declining economic productivity. The World Bank group (2017) reports that South Africa's economic productivity declined by $6 \%$ from 2007 to 2016 for various reasons.

A number of South African studies have identified correlates of work engagement to include functional 
resources such as behavioural adaptability, self-esteem (Venter, Coetzee, \& Basson, 2014), sense of coherence (Haley, Mostert, \& Els, 2014), PsyCap (Simons \& Buitendach, 2013), and work autonomy (De Klerk, Nel, \& Koekemoer, 2015). Specifically, employee propensities such as their proactive behaviour towards strengths use (Stander, Mostert, \& De Beer, 2014) and psychological meaningfulness (Chikoko, Buitendach, \& Kanengoni, 2015) significantly influenced work engagement. Furthermore, job characteristics such as role clarity (De Villiers \& Stander, 2014) and more specifically work-role fit (Diedericks \& Rothmann, 2014) play a role in employee work engagement.

Organisational factors for employee work engagement include work-related development opportunities (De Klerk, Nel, \& Koekemoer, 2015), empowering performance management (Kotzé, Van der Westhuizen, \& Nel, 2015), and organisational support for strengths use (Stander, Mostert, \& De Beer, 2014). Diedericks and Rothmann (2014) found that poor relationships between employees and supervisors are related to lower levels of engagement. Thus, authentic leadership (Stander, De Beer, \& Stander, 2015) and positive leaderships (Nel, Stander, \& Latif, 2015) are significantly related to work engagement. Studies are needed to construct explanatory models that address the individual and organisational level factor influences on employee work engagement.

\section{Goal of the study}

This study aimed to construct and confirm a model to explain work engagement from its antecedents of authentic leadership, PsyCap and followership. It sought to address the question: To what extent do authentic leadership, PsyCap and followership explain work engagement?

\section{Method}

\section{Participants and setting.}

We sampled employees from the South African health sector industry $(n=647$; females $=77.4 \%$; Afrikaans speaking $=65.8 \%$; post school education $=52.7 \%$; mean age $=45$ years, $\mathrm{SD}=8)$ and from the South African mining industry $(n=254$; males $=85 \%$, Afrikaans speaking = $44.1 \%$; post school education $=60.2 \%)($ see Table 1$)$.

In terms of job tenure, participants from the health sector industry had an average of eleven years of service in the organisation, whilst those from the mining industry had an average of 14 years of service. The average reporting period to the current manager was four years in both samples. In both samples, the average age of respondents was 45 years (with $\mathrm{SD}=8$ years in the health sector industry, and $\mathrm{SD}=9$ years in the mining industry).

\section{Measuring instruments}

The employees completed the Utrecht Work Engagement Scale (UWES: Schaufeli \& Bakker, 2003), Psychological

Table 1. Frequency distribution of the demographic characteristics of Sample 1 and Sample 2

\begin{tabular}{|c|c|c|c|c|c|}
\hline Group & Sub-group & Sample $1(\mathrm{~N})$ & Sample $1(\%)$ & Sample $2(\mathrm{~N})$ & Sample $2(\%)$ \\
\hline \multirow[t]{2}{*}{ Gender } & Male & 126 & $22.6 \%$ & 216 & $85 \%$ \\
\hline & Female & 501 & $77.4 \%$ & 48 & $15 \%$ \\
\hline \multirow[t]{6}{*}{ Occupational level } & Generally trained office worker / secretary & 1 & $0.2 \%$ & 7 & $2.8 \%$ \\
\hline & $\begin{array}{l}\text { Vocationally trained crafts-person, technician, } \\
\text { IT-specialist, nurse, artist or equivalent }\end{array}$ & 13 & $2 \%$ & 21 & $8.3 \%$ \\
\hline & $\begin{array}{l}\text { Academically trained professional or equivalent (but } \\
\text { not a manager of people) }\end{array}$ & 71 & $11 \%$ & 54 & $21.3 \%$ \\
\hline & $\begin{array}{l}\text { Manager of one or more sub-ordinates } \\
\text { (non-managers) }\end{array}$ & 362 & $56 \%$ & 129 & $50.8 \%$ \\
\hline & Manager of one or more managers & 162 & $25 \%$ & 25 & $9.8 \%$ \\
\hline & Other & 38 & $5.9 \%$ & 14 & $5.5 \%$ \\
\hline \multirow[t]{10}{*}{ Home language } & Afrikaans & 426 & $65.8 \%$ & 112 & $44.1 \%$ \\
\hline & English & 145 & $22.4 \%$ & 32 & $12.6 \%$ \\
\hline & Afrikaans \& English & 22 & $3.4 \%$ & - & - \\
\hline & North Sotho & 7 & $1.1 \%$ & 5 & $2 \%$ \\
\hline & South Sotho & - & - & 15 & $5.9 \%$ \\
\hline & Sepedi & 6 & $0.9 \%$ & - & - \\
\hline & Zulu & 6 & $0.9 \%$ & 6 & $2.4 \%$ \\
\hline & Tswana & 6 & $0.9 \%$ & 52 & $20.5 \%$ \\
\hline & Setswana & 5 & $0.8 \%$ & - & - \\
\hline & $\begin{array}{l}\text { Others: German, Russian; Xhosa, Ndebele, Shona, } \\
\text { Tsonga, Venda and other indigenous languages. }\end{array}$ & 24 & $3.8 \%$ & 18 & $7.1 \%$ \\
\hline \multirow[t]{6}{*}{ Educational level } & Secondary school & 2 & $0.3 \%$ & 14 & $5.5 \%$ \\
\hline & Matric or equivalent & 26 & $4 \%$ & 74 & $29.1 \%$ \\
\hline & Post-school certificate or diploma & 242 & $37.4 \%$ & 74 & $29.1 \%$ \\
\hline & University degree & 179 & $27.7 \%$ & 48 & $18.9 \%$ \\
\hline & Postgraduate degree & 162 & $25 \%$ & 31 & $12.2 \%$ \\
\hline & Other & 36 & $5.6 \%$ & 12 & $4.7 \%$ \\
\hline \multirow[t]{2}{*}{ Manager gender } & Male & 275 & $42.5 \%$ & 228 & $89.8 \%$ \\
\hline & Female & 372 & $57.5 \%$ & 26 & $10.2 \%$ \\
\hline
\end{tabular}


capital questionnaire (PCQ: Luthans, Youssef \& Avolio, 2007), Followership Survey (FS: Kelley, 1992), and the Authentic Leadership Questionnaire (ALQ: Avolio, Gardner, and Walumbwa (2007). They also self-reported their demographics.

With regards to the construct validity of the instruments, CFA was carried out to determine the fit of the sample responses to the original conceptualisation of the instruments (in Sample 1). The fit indices were evaluated for goodness of fit, as per the suggestions of Hair, Black, Babin and Anderson (2010). Where CFA showed less than acceptable results, Exploratory Factor Analysis (EFA) was employed to try and improve the model fit.

It was found that the PCQ and ALQ retained its original factor structure and items. The UWES presented a uni-dimensional factor structure, in contrast to the suggested three-dimensional structure. All items were retained. In contrast, the FS, after five rounds of EFA and loss of nine items, presented a two factor structure. The conceptualisation of these two factors was different to the original factor structure of the instrument and one of the dimensions was renamed. See Table 2 for the fit indices.

\section{Utrecht Work Engagement Scale}

The UWES consists of 17 items that are scored on a sevenpoint Likert scale $(0=$ never, to $6=$ always $)$. Previous South African studies reported scores from the UWES to have good internal consistency reliability, ranging from 0.78 for vigour and 0.78 for absorption, to 0.89 for dedication (Storm \& Rothmann, 2003). Using the UWES as unidimensional, Łaba and Geldenhuys (2016) reported Cronbach's alpha reliability of 0.90 . The internal reliability of scores from the unidimensional UWES in the present study sample was 0.924 .

\section{Psychological Capital Questionnaire}

The PCQ consists of 24-items to measure the four dimensions; namely self-efficacy, hope, resilience, and optimism. It scores on a six-point Likert scale $(1=$ strongly disagree, to $6=$ strongly agree). Scores from the PCQ indicated evidence of adequate reliability ranging from 0.67 to 0.90 (Görgens-Ekermans \& Herbert, 2013; Simons $\&$ Buitendach, 2013). The internal reliability of scores from the PCQ in the present sample was 0.891 .

\section{Followership Survey}

The FS is a 20 -item measure of active engagement (10 items) and independent critical thinking (10 items). Items are scored on a seven-point Likert scale $(1=$ rarely, to 7 $=$ almost always). Previous studies reported satisfactory reliability coefficients for scores from the FS of 0.68 to 0.87 (Tanoff \& Barlow, 2002; Vandoren, 1998). The internal reliability of scores from the FS in the present study was 0.793 .

\section{Authentic Leadership Questionnaire}

The ALQ comprises 16-items to measure four subscales of authentic leadership; namely self-awareness, relational transparency, balanced processing, and internalised moral perspective (Luthans \& Avolio, 2003). Items are scored on a five-point Likert scale ( $0=$ not at all, to $4=$ frequently). A previous South African study using a health care industry sample reported reliability coefficients of 0.93 for scores from the ALQ (Stander et al., 2015). The internal reliability of scores from the ALQ in the present study was 0.953 .

\section{Research procedure}

The study was approved by the Ethics Committee of the University of the Western Cape (Project number 13/5/36). The participants individually consented to participate in the study. Potential respondents individually received the composite questionnaire via e-mail. Where participants did not have access to e-mail, a paper and pencil version was provided. Through the information page/letter, participants were assured that their responses would be treated confidentially. Furthermore, it was emphasised that participation in the study was voluntary and participants could withdraw from the study at any time without any risk or penalty.

\section{Data analysis}

The Statistical Package for the Social Sciences (SPSS, Version 21) was used to provide the descriptive and inferential statistics. In addition, AMOS software (Version 21) was used to conduct confirmatory factor analysis (CFA) and to test the fit of the structural equations model (SEM) (see also Table 2) and structural equivalence of measurement instruments.

\section{Testing of the theoretical model}

For our structural modelling, the averaged item scores of the respective dimensions of the ALQ, PCQ and FS served as the observed variables. The model therefore consisted of four latent variables, namely:

- Authentic leadership, consisting of four observed variables: transparency, moral/ethical, balanced processing, and self-awareness.

- PsyCap, consisting of four observed variables: efficacy, hope, resilience, and optimism.

- Followership, consisting of two observed variables: initiative and independent thinking.

Work engagement, consisting of five observed variables. These five observed variables are the averaged

Table 2. Final structural equivalence of measurement instruments results for Sample 1

\begin{tabular}{lccccc}
\hline Construct & Number of dimensions & $\chi^{2} / \mathrm{df}$ & RMSEA & NFI & 0.991 \\
Work engagement & 1 & 4.500 & 0.074 & 0.993 & 0.042 \\
PsyCap & 4 & 2.151 & 0.987 & 0.993 \\
Followership & 2 & 5.896 & 0.929 & 0.940 \\
Authentic leadership & 4 & 5.961 & 0.088 & 0.949 \\
\hline
\end{tabular}


Table 3. Fit indices of the structural model for Samples 1 and 2

\begin{tabular}{lcc}
\hline Indices & Sample 1 & Sample 2 \\
\hline$\chi^{2}$ & 227.565 & 102.452 \\
df & 84 & 84 \\
$\chi^{2} /$ df & 2.709 & 1.220 \\
AIC & 299.565 & 174.452 \\
RMSEA & 0.051 & 0.029 \\
RMR & 0.069 & 0.099 \\
NFI & 0.965 & 0.958 \\
CFI & 0.977 & 0.992 \\
\hline
\end{tabular}

totals of the five parcels created to confirm the factor structure of the UWES for the current sample. Parcelling was done due to the unidimensional nature of the instrument.

Paths were drawn from authentic leadership to PsyCap, followership, and work engagement, respectively. Furthermore, a path was drawn from PsyCap to work engagement and followership, respectively. Lastly, a path was drawn from followership to work engagement. Based on the conceptualisation of the model, various mediation paths are also implied. The parameter of one of the observed variables per latent variable was constrained to 1. The exact procedure was also used to test the structural model as applied to Sample 2. The results of the parameter testing to determine the fit of the structural model can be seen in Table 3.

The results in Table 3 present an overall good fit of the structural equations model for the samples. The RMSEA of 0.051 for Sample 1 falls within the range of $0.05-0.08$, representing acceptable fit. The RMSEA for Sample 2 shows good fit at 0.029. Furthermore, the $\chi^{2} / \mathrm{df}$ for Sample 1 is 2.709 , which falls within the good fit guideline of $2-$ 5. The $\chi^{2} /$ df statistic for Sample 2 is on the lower side, but this could be attributed to sample size. The incremental fit indices for Samples 1 and 2 are all greater than 0.9, which indicates good fit. The good fit of the model in Sample 1 implies that the model has some value in the healthcare industry to explain the sequential relationships between the variables. By confirming the model in the second sample (i.e., in the mining industry), it is likely that the model can be generalised across additional samples.

\section{Mediation analysis}

In the theoretical model, PsyCap mediates the relationship between authentic leadership and work engagement. Mediation analysis was done through a series of regression analyses in SPSS using the Baron and Kenny approach (1986). The regression results indicate that both authentic leadership $(\beta=0.12, \mathrm{t}(2,644)=4.040, \mathrm{p}<0.001)$ and PsyCap $(\beta=0.80, \mathrm{t}(2,647)=15.00, \mathrm{p}<0.000)$ remain as significant predictors of work engagement. Therefore, PsyCap partially mediates the relationship between authentic leadership and work engagement. The Sobel test indicates that the partial mediation is statistically significant $(\mathrm{z}=8.67, \mathrm{p}<0.00)$.

When analysing the mediating role of followership in the relationship between authentic leadership and work engagement, the same process was followed (see Baron \&
Kenny, 1986). In Step 1 (the regression of $X \rightarrow Y$, ignoring the mediator), authentic leadership was found to be significantly positively associated with work engagement $(\beta=0.29, \mathrm{SE} \beta=0.03, \mathrm{t}(1,645)=3.14, \mathrm{p}<0.001)$. In Step 2 (the regression of the $X \rightarrow M$ ), the results indicated that authentic leadership is not significantly associated with followership $(\beta=0.04, t(1,645)=0.04, p=0.196)$. Step 3 (the regression of $\mathrm{M} \rightarrow \mathrm{Y}$ ) indicated that followership and work engagement was found to be significantly associated $(\beta=0.39, \operatorname{SE} \beta=0.04, \mathrm{t}(2,647)=10.19, \mathrm{p}<0.001)$. As all three paths in the mediation model were not found to be statistically significant, it was found that followership is not a mediator of the effect of authentic leadership on work engagement.

\section{Results and discussion}

The standardised path coefficients between the variables are displayed in Figure 1. The coefficient for Sample 1 is given first, with the coefficient for Sample 2 following after the forward slash.

\section{PsyCap and authentic leadership influences.}

From Figure 1, it can be observed that the pattern of path coefficients estimated for Sample 1 and 2 is fairly similar. PsyCap explains the single biggest proportion of the variance in followership $(p<0.001 / p<0.01)$ and work engagement $(p<0.001)$. There is also a significant relationship between authentic leadership and PsyCap ( 0.39 and 0.41 respectively, $p<0.001$ ). The relationship between authentic leadership and followership is negligible, but some relationship between followership and work engagement is observed (0.14) in Sample 1.

The path coefficients indicate that authentic leadership, PsyCap and followership are significant influences on employee work engagement. Although no previous studies have tested the current conceptualisation of the research model, the findings confirm previous studies examining the relationship between work engagement and, respectively, authentic leadership (Stander et al., 2015) and PsyCap (Simons \& Buitendach, 2013). The negligible relationship between authentic leadership and followership is not in line with studies highlighting the need for good relationships between leaders and followers (Diedericks \& Rothmann, 2014; Els et al., 2016; Palo \& Rothmann, 2016). This discrepancy in findings is a matter for further explanatory research.

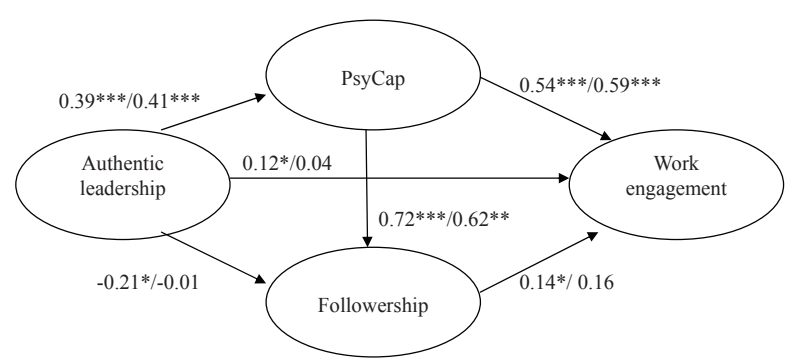

Note. $* \mathrm{p}<0.05, * * \mathrm{p}<0.01, * * * \mathrm{p}<0.001$; Path coefficients are noted in the following format: path coefficient sample 1/path coefficient Sample 2.

Figure 1: Diagram of the SEM model with standardised regression weights for Samples 1 and 2 
The results indicated that PsyCap was a partial mediator of the relationship between authentic leadership and work engagement. This finding is consistent with previous findings of PsyCap as a mediator between authentic leadership and important workplace outcomes (Wang, Sui, Luthans, Wang, \& Wu, 2014). Although no other studies have reported on the mediating role of PsyCap between authentic leadership and work engagement, PsyCap has been found to moderate the relationship between authentic leadership and performance (Wang et al., 2014). Avey, Wernsing, and Luthans (2008) stated that employees with higher levels of PsyCap tended to proactively facilitate positive changes in the organisation. Therefore, PsyCap is an important employee resource for organisational performance.

Authentic leadership does have a direct influence on work engagement. However, this influence is increased as a result of the mediating role of PsyCap. Individuals with self-efficacy, hope, optimism, and resilience have work engagement across a variety of leadership regimens (Stander et al. 2015; Tims, Bakker \& Xanthapoulou, 2011). Wang and colleagues (2014) proposed that PsyCap may be a substitute for authentic leadership. If this was the case, then individuals with a high level of positive psychological capacities would not be dependent on the leader's efforts to be work engaged.

\section{Implications for research and practice}

The results of the present study indicate that PsyCap explains the biggest unique proportion of the variance in work engagement when controlling for the influence of the other variables. Therefore, PsyCap training and microinterventions could impact the level of work engagement in a positive manner (Luthans et al., 2007). Interventions to enhance work engagement levels in the organisation could also be focused on enhancing vigour, dedication, and absorption directly. Bakker's (2009) "Engagement Monitor" is one such example where employees would receive personal feedback and benchmarking of their engagement scores. Individual coaching can be utilised to address low levels of work engagement and as part of training programmes in organisational health and individual well-being (Schaufeli \& Salanova 2007).

\section{Limitations of the study}

The limitations of the research design include use of selfreport data which is susceptible to social desirability responding. Moreover, the present study purposively selected respondents who formed part of the managerial level of the organisation. Therefore, the findings do not generalise to the organisation as a whole. Furthermore, the non-probability sampling technique utilised to invite responses to the survey would have an impact on the generalisability of the findings.

\section{Conclusion}

The results of the present study indicate that PsyCap explains the biggest unique proportion of the variance in work engagement when controlling for the influence of the other variables. Therefore, PsyCap training and micro-interventions could impact the level of work engagement in a positive manner. Confirming the direct impact of authentic leadership as well as PsyCap on work engagement adds to the empirical findings on the antecedents of work engagement.

\section{Author note}

This work is based on the research supported in part by the National Research Foundation of South Africa. Any opinion, finding and conclusion or recommendation expressed in this material is that of the authors and the NRF does not accept any liability in this regard. This work is based on the $\mathrm{PhD}$ study of the corresponding author.

\section{ORCID}

Marieta du Plessis iD http://orcid.org/0000-0002-3865-6959

\section{References}

Attridge, M. (2009). Measuring and Managing Employee Work Engagement: A Review of the Research and Business Literature. Journal of Workplace Behavioral Health, 24(4), 383-398, DOI: 10.1080/15555240903188398

Avolio, B. J., Gardner, W. L., \& Walumbwa, F. O. (2007). Authentic Leadership Questionnaire (ALQ) [Measurement instrument]. Retrieved from http://www.mindgarden.com

Avey, J. B., Wernsing, T. S., \& Luthans, F. (2008). Can positive employees help positive organizational change? Impact of psychological capital and emotions on relevant attitudes and behaviors. The Journal of Applied Behavioral Science, 44(1), 48-70. https://doi.org/10.1177/0021886307311470

Baker, S. D. (2007). Followership: The theoretical foundation of a contemporary construct. Journal of Leadership \& Organizational Studies, 14(1), 50-60. https://doi. org/10.1177/0002831207304343

Bakker, A. B. (2009). Building engagement in the workplace. In R. J. Burke \& C. L. Cooper (Eds.), The peak performing organization (pp. 50-72). Oxon, UK: Routledge. https://doi. org/10.4324/9780203971611.ch3

Bakker, A. B., \& Demerouti, E. (2008). Towards a model of work engagement. Career Development International, 13(3), 209-223. https://doi.org/10.1108/13620430810870476

Baron, R. M., \& Kenny, D. A. (1986). The moderator-mediator variable distinction in social psychological research: Conceptual, strategic, and statistical considerations. Journal of Personality and Social Psychology, 51(6), 1173-1182. https://doi.org/10.1037/0022-3514.51.6.1173

Barrick, M. R., Thurgood, G. R., Smith, T. A., \& Courtright, S. H. (2015). Collective organizational engagement: Linking motivation antecedent, strategic implementation, and firm performance. Academy of Management Journal, 58, 111-135. https://doi.org/10.5465/amj.2013.0227

Cameron, K. S., \& Spreitzer, G. M. (2012). Introduction: What is positive about Positive Organizational Scholarship? In K. S. Cameron \& G. M. Spreitzer (Eds.), The Oxford Handbook of Positive Organizational Scholarship (pp. 1-14). New York: Oxford University Press. 10.1093/ oxfordhb/9780199734610.001.0001

Chikoko, G. L., Buitendach, J. H., \& Kanengoni, H. (2014). The psychological conditions that predict work engagement among tertiary education employees. Journal of Psychology in Africa, 24(6), 469-474.

Coetzer, M. F., Bussin, M. H., \& Geldenhuys, M. (2017). Servant leadership and work-related well-being in a construction companySA Journal of Industrial Psychology, 43, 1-10. https://doi.org/10.4102/sajip.v43i0.1478

Dawsey, J. C. \& Taylor, E. C. (2011). Active engagement to active disengagement: A Proposed model. Business Studies Journal, 3(1), 29-42. 
De Klerk, M. D., Nel, J. A., \& Koekemoer, E. (2015). Work-tofamily enrichment: Influences of work resources, work engagement and satisfaction among employees within the South African context. Journal of Psychology in Africa, 25(6), 537-546.

De Villiers, J. R., \& Stander, M. W. (2011). Psychological empowerment, work engagement and turnover intention: The role of leader relations and role clarity in a financial institution. Journal of Psychology in Africa, 21(3), 405-412.

Diedericks, E., \& Rothmann, S. (2013). Flourishing of information technology professionals: The role of work engagement and job satisfaction. Journal of Psychology in Africa, 23(2), 225-233.

Els, C., Viljoen, J., Beer, L. D., \& Brand-Labuschagne, L. (2016). The mediating effect of leader-member exchange between strengths use and work engagement. Journal of Psychology in Africa, 26(1), 22-28.

Engelbrecht, A. S., Heine, G., \& Mahembe, B. (2014). The influence of ethical leadership on trust and work engagement: An exploratory study. SA Journal of Industrial Psychology, 40(1), 1-9. https://doi.org/10.4102/sajip.v40i1.1210

Gibbons, J., \& Schutt, R. (2010). A Global Barometer for Measuring Employee Engagement. (Research Working Group Report No. 1460-09-RR). Retrieved from http://www. conference-board.org

Görgens-Ekermans, G., \& Herbert, M. (2013). Psychological capital: Internal and external validity of the Psychological Capital Questionnaire (PCQ-24) on a South African sample. SA Journal of Industrial Psychology, 39(2), 1-12. doi: 10.4102/sajip.v39i2.1131

Hair, J. F., Black, W. C., Babin, B. J., \& Anderson, R. E. (2010). Multivariate data analysis: A global perspective. Upper Saddle River, NJ: Pearson Education, Inc.

Harter, J. K., Schmidt, F. L., \& Keyes, C. L. (2003). Well-being in the workplace and its relationship to business outcomes: A review of the Gallup studies. In C.L. Keyes \& J. Haidt (Eds.), Flourishing: The Positive Person and the Good Life (pp 205-224). Washington D.C.: American Psychological Association.

Haley, L., Mostert, K., \& Els, C. (2013). Burnout and work engagement for different age groups: Examining group-level differences and predictors. Journal of Psychology in Africa, 23(2), 283-296

Kelley, R. E. (1992). The power of followership: How to create leaders people want to follow and followers who lead themselves. New York: Doubleday.

Kotzé, J., van der Westhuizen, S., \& Nel, E. (2014). The relationship between employees' experience of performance management and work engagement within a South African organisation. Journal of Psychology in Africa, 24(6), 475-479.

Łaba, K., \& Geldenhuys, M. (2016). Psychological availability and work engagement: The moderating role of sex and race. Journal of Psychology in Africa, 26(2), 107-112.

Lockwood, N. R. (2007). Leveraging employee engagement for competitive advantage. Society for Human Resource Management Research Quarterly, 1, 1-12.

Luthans, F., \& Avolio, B. J. (2003). Authentic leadership: a positive developmental approach. In K. S. Cameron, J. E. Dutton, \& R. E. Quinn (Eds.), Positive organizational scholarship: foundations of a new discipline (pp. 241-258). San Francisco, CA: Berrett-Koehler.

Luthans, F., Avolio, B. J., Avey, J. B., \& Norman, S. M. (2007). Positive psychological capital: Measurement and relationship with performance and satisfaction. Personnel Psychology, 60(3), 541-572. https://doi. org/10.1111/j.1744-6570.2007.00083.x

Luthans, F., Van Wyk, R., \& Walumbwa, F. O. (2004). Recognition and development of hope for South African organizational leaders. Leadership and Organization Development Journal, 25(6), 512-527. https://doi. org/10.1108/01437730410556752
Luthans, F., \& Youssef-Morgan, C. M. (2017). Psychological capital: An evidence-based positive approach. Annual Review of Organizational Psychology and Organizational Behavior, 4(1), 339-366. https://doi.org/10.1146/ annurev-orgpsych-032516-113324

Luthans, F., Youssef, C. M., \& Avolio, B. J. (2007). Psychological capital: Developing the human capital edge. Oxford, England: Oxford University Press.

May, D., Gilson, R., \& Harter, L. (2004). The psychological conditions of meaningfulness, safety and availability and the engagement of the human spirit at work. Journal of Occupational and Organizational Psychology, 77(1), 11-37. https://doi.org/10.1348/096317904322915892

Mitonga-Monga, J., Flotman, A. P., \& Cilliers, F. (2016). Workplace ethics culture and work engagement: The mediating effect of ethical leadership in a developing world context. Journal of Psychology in Africa, 26(4), 326-333.

Nel, T., Stander, M. W., \& Latif, J. (2015). Investigating positive leadership, psychological empowerment, work engagement and satisfaction with life in a chemical industry. $S A$ Journal of Industrial Psychology, 41(1), 1-13. https://doi. org/10.4102/sajip.v41i1.1243

Palo, J., \& Rothmann, S. (2016). Work engagement in the mining industry in South Africa: The role of tasks and relationships. Journal of Psychology in Africa, 26(3), 221-229.

Rich, B. L., LePine, J. A., \& Crawford, E. R. (2010). Job engagement: Antecedents and effects on job performance. Academy of Management Journal, 53(3), 617-635. https:// doi.org/10.5465/AMJ.2010.51468988

Robertson, I. T., \& Cooper, C. L. (2010). Full engagement: The integration of employee engagement and psychological well-being. Leadership and Organization Development Journal, 31(4), 324-336. https://doi. org/10.1108/01437731011043348

Rothbard, N. P., \& Patil, S. V. (2012). Being there: Work engagement and Positive Organizational Scholarship. In K. S. Cameron \& G. M. Spreitzer (Eds.), The Oxford handbook of positive organizational scholarship (pp. 56-69). New York, NY: Oxford University Press.

Rothmann, S. (2017). Employee engagement. In L. G. Oades, M. Steger, A. Delle-Fave, \& J. Passmore (Eds.), The Wiley-Blackwell handbook of the psychology of positivity and strengths-based approaches at work (pp. 317-341). Chichester: Wiley.

Schaufeli, W. B. (2014). What is engagement? In C. Truss, R. Delbridge, E. Soane, K. Alfes, \& A. Shantz (Eds.), Employee engagement in theory and practice (pp. 15-35). London, UK: Routledge.

Schaufeli, W. B., \& Bakker, A. B. (2003). UWES Utrecht Work Engagement Scale: Preliminary manual (Version 1) [Measuring instrument]. Utrecht University: Occupational Health Psychology Unit.

Schaufeli, W. B., Bakker, A. B., \& Salanova, M. (2006). The measurement of work engagement with a short questionnaire. Educational and Psychological Measurement, 66(4), 701-716. https://doi.org/10.1177/0013164405282471

Schaufeli, W. B., \& Salanova, M. (2007). Efficacy or inefficacy: that's the question: Burnout and work engagement and their relationships with efficacy beliefs. Anxiety, Stress, and Coping, 20(2), 177-196. https://doi. org $/ 10.1080 / 10615800701217878$

Simons, J. C., \& Buitendach, J. H. (2013). Psychological capital, work engagement and organisational commitment amongst call centre employees in South Africa. [-pages.]. SA Journal of Industrial Psychology, 39(2), 1-12. https://doi. org/10.4102/sajip.v39i2.1071

Stander, F. W., De Beer, L. T., \& Stander, M. W. (2015). Authentic leadership as a source of optimism, trust in the organisation and work engagement in the public health care sector. SA Journal of Human Resource Management, 13(1), 1-12. https://doi.org/10.4102/sajhrm.v13i1.675 
Stander, F. W., Mostert, K., \& De Beer, L. T. (2014). Organisational and individual strengths use as predictors of engagement and productivity. Journal of Psychology in Africa, 24(5), 403-409.

Storm, K., \& Rothmann, S. (2003). A psychometric analysis of the Utrecht Work Engagement Scale in the South African police service. SA Journal of Industrial Psychology, 29(4), 62-70. https://doi.org/10.4102/sajip.v29i4.129

Tanoff, G. F., \& Barlow, C. B. (2002). Leadership and followership: Same animal, different spots? Consulting Psychology Journal: Practice and Research, 54(3), 157-165. https://doi.org/10.1037/1061-4087.54.3.157

Tims, M., Bakker, A. B., \& Xanthopoulou, D. (2011). Do transformational leaders enhance their followers' daily work engagement?. The Leadership Quarterly, 22(1), 121-131.

Truss, C., Delbridge, R., Alfes, K., Shantz, A., \& Soane, E. (2014). Introduction. In C. Truss, R. Delbridge, E. Soane, K. Alfes, \& A. Shantz (Eds.), Employee engagement in theory and practice (pp. 1-11). London, UK: Routledge.

VanDoren, E. (1998). The relationship between leadership/ followership in staff nurses and employment setting (Unpublished aster's thesis). Western Michigan University, Kalamazoo, United States of America.
Venter, J., Coetzee, M., \& Basson, J. S. (2013). Psychological career resources and work engagement of early career consulting staff. Journal of Psychology in Africa, 23(3), 431-438.

Wang, D., \& Hsieh, C. (2013). The effect of authentic leadership on employee trust and employee engagement. Social Behavior and Personality, 41(4), 613-624. https://doi. org/10.2224/sbp.2013.41.4.613

Wang, H., Sui, Y., Luthans, F., Wang, D., \& Wu, Y. (2014). Impact of authentic leadership on performance: Role of followers' positive psychological capital and relational processes. Journal of Organizational Behavior, 35(1), 5-21. https://doi.org/10.1002/job.1850

World Bank Group. (2017). South Africa economic update: Innovation for productivity and inclusiveness. The World Bank. Retrieved from: http://documents.worldbank.org/ curated/en/779551505322376708/pdf/119695-WP-PUBLICSA-EU-2017-Digital-Version-Sep-19.pdf 